\title{
GROUNDING TANTRIC PRAXIS IN THE MAHĀYĀNA MEANING AND MODES:
}

\author{
AN EXOTERIC DOXOGRAPHY CONTAINED IN THE TANGUT WORK \\ NOTES ON THE KEYPOINTS OF MAHĀMUDRĀ AS THE ULTIMATE ${ }^{1}$
}

\author{
ZHANG LINGHUI \\ Religious Studies Department, University of Virginia \\ 1540 Jefferson Park Avenue, Charlottesville, VA 22903, USA \\ e-mail: dzamlingod@gmail.com
}

This paper explores a sūtra-based doxography contained in the 12th-century Tangut Mahāmudrā work Notes on the Keypoints of Mahāmudrā as the Ultimate. It employs the doctrinal complex of the doxography to demonstrate the common Mahāyāna discursive framework within which the tantra-originated Mahāmudrā has grounded its meaning. It further argues that the doxography integrates the Yogācāra-Madhyamaka and Buddha-nature currents of thought as the philosophical ground for Mahāmudrā.

Key words: Tangut Buddhist literature, Tibetan Buddhism, Mahāmudrā, Mahāyāna scholasticism, tantric Buddhism, Yogācāra-Madhyamaka, Buddha-nature.

Xixia Buddhist literature ${ }^{2}$ concerning Tibetan Buddhist subjects contains a variety of tantric and yogic teachings ${ }^{3}$ in combination with a range of doctrinal composi-

${ }^{1}$ I owe my gratitude to a number of individuals who contributed in different ways to bringing this paper to its present form. I am grateful to Professor Kirill Solonin (Renmin University of China) for assisting me in translating the Tangut texts relevant to my research. I also owe my thanks to the two anonymous reviewers for their valuable suggestions. In addition, I should thank Mr. Andrew Taylor (University of Virginia) for proofreading the English of this paper. My thanks also go to the Khyentse Foudation for providing me with the financial support to cover the research and writing for this paper.

${ }^{2}$ I use 'Xixia literature' or 'Xixia texts' to refer to both Tangut- and Chinese-language texts pertaining to the Xixia regime. I follow most Tangutologists' practice of using Chinese graphs to present the Tangut content through a semantic rendering. These reconstructions (e.g. ‘釋迦” as the

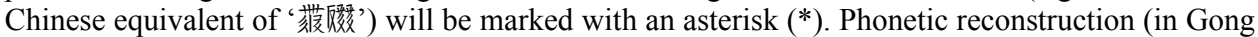
Hwang-cherng's system) will be provided for the Tangut term (e.g. sjji kja 隺韨). I rely on Nevskij (1960) and $\mathrm{Li} \mathrm{(2012)} \mathrm{as} \mathrm{for} \mathrm{my} \mathrm{translation} \mathrm{tools.}$

${ }^{3}$ The term 'tantric Buddhism' as part of the standard vocabulary of religious studies is heavily invested with the dialectics between traditional self-expression and modern scholarly constructs. It is commonly acknowledged that what distinguishes tantric Buddhism from non-tantric 
tions. ${ }^{4}$ It provides a window into the 12 th-century Tibetan attempts to assimilate and systematise the yogic, ritual, and philosophical currents that represent the latest developments of Indian Buddhism. Nikolai Nevskij (1892-1937) was the first to identify two major constituents of Tangut Buddhism, the Sinitic and the Tibetan. ${ }^{5}$ This line of work was later followed by Nishida Tatsuo 西田龍雄 (1928-2012) and Evgenij Kychanov (1932-2013). Based on their initial cataloguing of Tangut Buddhist literature, the two scholars identified important aspects of Tibetan Buddhism present within the corpus. $^{6}$ In the 21 st century, scholarly knowledge of various Indo-Tibetan Buddhist yogic transmissions which ended up in Xixia has advanced thanks to the discovery of the importance of the Dasheng yaodao miji 大乘要道密集 (The secret collection of works on the essential path of Mahāyāna; 'DYM'). This collection of Tibetan tantric Buddhist works in Chinese translation was compiled throughout the 13th and 14th centuries. ${ }^{7}$

The paper investigates a doxographical fragment ${ }^{8}$ which serves as the philosophical ground for a Mahāmudrā system that embraces both the sūtric and tantric paths to ultimacy. The doxography is found in the Khara Khoto Tangut work Notes on the

Mahāyāna lies in the former's predominant claim to ritual and yogic implementations as a means towards the ultimate goal of awakening. Here 'yogic' is used to reference one manipulating his/her own psycho-physiological processes so as to reveal a divine subtle body form and a blissful, luminous, and non-conceptual gnosis.

${ }^{4}$ See Solonin 2011, 2012, 2015 and 2016.

${ }^{5}$ See Nevskij 1960.

${ }^{6}$ Nishida and Kychanov have identified the titles and authors of a good number of Khara Khoto Tangut Buddhist works; see Nishida 1977 and 1999; Kychanov 1999.

${ }^{7}$ Attributed to the Sa skya patriarch 'Phags pa Blo gros rgyal mtshan $(1235-1280)$ as the compiler, the $D Y M$ contains a substantial number of works affiliated with Tibetan Buddhist traditions other than the Sa skya sect. For instance, approximately one third of the collection concerns the Mahāmudrā teaching transmitted through bKa' brgyud teachers. Back in the early 20th century, Lü Cheng 呂澄 (1896-1989) was the first one to apply an academic historical-philological approach to studying the DYM; see Lü 1942. Christopher Beckwith introduced the collection to the English academic world; see Beckwith 1984. Chen Qingying 陳慶英 first noted an intimate connection with the Tangut Xixia in the DYM; see Chen 2003. Shen Weirong 沈衛榮 further builds a textual connection between the DYM and Chinese translations of Tibetan tantric texts from the Khara Khoto collection and ascribes most of the DYM titles to translations completed under the Xixia and Yuan; see Shen 2007. For more detailed examinations of the transmission history of these Tibetan tantric teachings from Tibet to Xixia based on both the Khara Khoto Buddhist texts pertaining to Tibetan subjects and the DYM Chinese translations, see Dunnell 2011, Sun 2014 and Solonin 2015.

${ }^{8}$ The term 'doxography' as it was applied in its original context referred to the collected summaries of different Greek philosophical views. Wilhelm Halbfass's (1988: 263-286, 349-368) usage follows the sense of 'the collection of philosophical views' and explores the roots of Indian doxographic thinking. Recently, quite a few Buddhist studies scholars have found the term useful, using it to label the Buddhist genre of doctrinal classification literature. Jacob Dalton (2005) applies 'doxography' to the tantric Buddhist classification schemes which mainly concern the difference in ritual and yogic practices. In this paper, I use 'doxography' to describe a particular type or genre of Buddhist writing characterised by the siddhānta (grub mtha') paradigm. The Buddhist siddhānta work sets forth the philosophical views of various schools-Buddhist and non-Buddhistin a systematic fashion, usually with an agenda of demonstrating the superiority of the author's own philosophical position. 


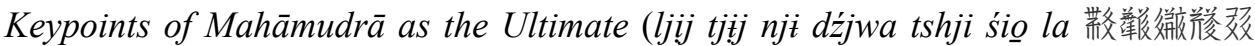
䧐妥㢆 * 大印究竟要集記; 'Notes'), a commentary on the Keypoints of Mahāmudrā as

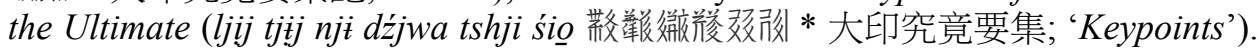
This paper demonstrates how the Notes doxography integrates the Yogācāra-Madhyamaka and Buddha-nature currents to reveal and account for the common Mahāyāna philosophical framework in which the tantra-originated Mahāmudrā has grounded its meaning.

The Keypoints-Notes cluster survives only in Tangut versions in the Khara Khoto collection. Tang. 345 contains the Keypoints in xylography (Inv. 2526) and manuscript (Inv. 824), and the first (Inv. 2858 and Inv. 7163) and final (Inv. 2851) volumes of the Notes in manuscript. A separate copy of the Keypoints is found in Inv. 2876, and the Notes in Tang.\#inv. 427\#3817 (Vols. 1\&2). Discussions here will be based on the Keypoints (Tang.\#inv. 345\#2526) and the Notes (Tang.\#inv. 345\#2858).

Solonin (2011) provides a preliminary study of the Keypoints — on the basis of Tang.\#inv. 345\#2526 - in terms of its textual form, transmission lineage, formulaic framework for a philosophical narrative, and doctrinal connections with other Tangut Mahāmudrā texts. The work presents a twofold paradigm of Causal and Resultant Vehicles (i.e., sūtric and tantric) ${ }^{9}$ - each in nine stages - converging in their respective eighth stages of non-conceptuality (ljịr tśiow 崭信 * 無念; Skt. nirvikalpa) and culminating in the ninth, the Mahāmudrā. ${ }^{\overline{1}}$

The Keypoints not only reveals the Tangut interpretive agency in mapping the path of recognising the nature of reality and the mind, but also unpacks in contextually nuanced ways the multi-layered and diversely constituted topography of Indian Buddhist Tantra and scholasticism. The work represents one of the first attempts at a Mahāmudrā architecture which organises Buddhist thoughts and practices in a progressive 'path stage' (lam rim) structure. Initially a gnostic index of ultimacy derived from Buddhist Tantra, the term mahāmudrā gradually rose to act as an overarching rubric beyond both sūtra and tantra, a paradigm traceable in both Indian and Tibetan works (e.g. Maitrīpa's and sGam-po-pa's) as early as the 11 th or 12 th century. ${ }^{11}$ It was

${ }^{9}$ The Keypoints explains that the distinction between the resultant and causal vehicles is only a matter of whether the practitioner disengages (via the causal vehicle) or engages (via the

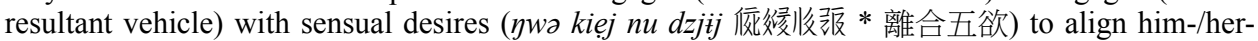
self with suchness (lew yiej śjwi 齐諬影 * 合一真), that is, non-conceptuality; see the Keypoints

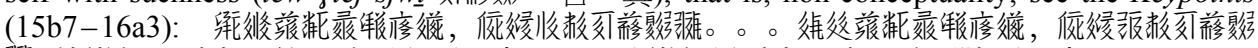

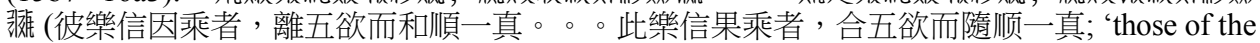
causal vehicle disengage themselves from the five sensual desires to align with suchness ... these of the resultant vehicle engage themselves with the five sensual desires to align with suchness'). This is the typical parameter adopted to distinguish between the sūtric and tantric modes of praxis. It is also found in the DYM. For instance, it is stated in the Guangming ding xuanyi 光明定玄義 $(G D X)$ that 'one who practices through abandoning kleśa practices the sūtric path, while one who practices without abandoning kleśa practices the tantric path' (若棄捨煩惱而修道者是顯教道, 不 捨煩惱而修道者是密教道); c.f. Shen 2017: 208. In terms of the Tibetan attitude towards the sūtratantra distinction, see Germano and Waldron 2006: 51-52; Almogi 2009: 76-77, Note 103.

${ }^{10}$ See Solonin 2011: 288-295.

${ }^{11}$ Roger Jackson (2005 and 2011) traces the semantic evolution of mahāmudrā along the development of Indian Buddhist Tantra. According to Jackson, mahāmudrā has undergone semantic 
not until the 16th century that Tibetan bKa' brgyud teachers (e.g. Dwags po bKra shis rnam rgyal and Padma dkar po) started to present this paradigm in such systematic and structured ways. Nonetheless, we find an early Tangut instance in our Keypoints which dates to the mid-12th century.

Furthermore, the Notes doxography which serves as a commentary on the Keypoints' opening verses allows deeper insights into how Mahāmudrā was accorded a traditional Mahāyāna philosophical ground. In the later phase of Indian Buddhism, as there were mutual processes of appropriation between tāntrikas seeking theoretical grounds for practices and monastics appropriating yogic ritualism, ${ }^{12}$ traditional Mahāyāna scholastic models and hermeneutics were adopted to engage the philosophical questions of tantra. It was in this context that tantric theorists read Mahāyāna sūtric philosophy and exoteric scholasticism into Mahāmudrā — a discourse highly charged with tantric connotations - on the basis of shared experiential grounds on non-conceptual realisation of the nature of the mind. ${ }^{13}$ The Notes doxography represents a 12th-century Tangut continuation of this Indo-Tibetan process of philosophising Mahāmudrā. Its systematic and structured presentation of philosophical threads drawn from the Buddhist scholastic pool again reflects the Tangut interpretative agency in deploying the discursive sources at their disposal for a philosophy for and of Mahāmudrā.

\section{The Lineage of the Keypoints-Notes Cluster}

The Xixia Mahāmudrā corpus consists of Tangut texts and fragments scattered across approximately 15 inventory numbers of the Khara Khoto collection (kept in the Institute of Oriental Studies, Russian Academy of Sciences), and Chinese ones - most of which have Tangut equivalents-included in the $D Y M{ }^{14}$ The entire corpus can be divided into two major clusters in terms of transmission lineage. The Keypoints-Notes

shifts from a ritual gesture in earlier Buddhist tantras, through one 'sealing' process of spiritual attainments in the more inward-oriented Mahāyoga- and Yoginī-tantras, to an index of ultimacy featured by the luminous and empty nature of the mind in the more gnostic siddha writings. Towards the final phase of Indian Buddhist Tantra, the usage of mahammudrā became evocative of philosophical themes resonant with Mahāyāna scholasticism.

${ }^{12}$ One remarkable phenomenon concomitant to this process was the tendency among Mahāyāna teachers to lay dual claims to both Vajrayānist and scholarly identities. For a sketch of the Vajrayānist appropriation of the Madhyamaka philosophy, see Ruegg 1981: 104-108. Worthy of note is the tendency of name appropriation Ruegg (1981: 105-106) has observed inside Vajrayāna Buddhist circles, that is, the retroactive projection of the identities of tantric masters onto earlier Mādhyamika teachers.

${ }^{13}$ See, for instance, Mathes 2006, 2007 and 2009.

${ }^{14}$ Solonin (2011) gives a detailed overview of the Tangut Mahāmudrā textual tradition and devotes lengthy discussions to the transmission and doctrine of the Keypoints. Shen (2007: 280-289) makes a descriptive catalogue of the DYM Chinese Mahāmudrā texts. Sun (2014) makes a comparative study of several Mahāmudrā texts between Tangut and Chinese recensions. For a recent publication containing the transliteration, translation and DYM Chinese equivalent (if available) of the Tangut Mahāmudrā texts, see Sun and Nie 2018. 
cluster presents a line starting from the Buddha, continuing through the Indian patriarchs Vimalakīrti (wji mo 并形技 * 維摩), Saraha (sja rjar xa 娒㔙带), Nāgārjuna (we

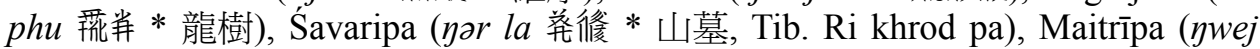

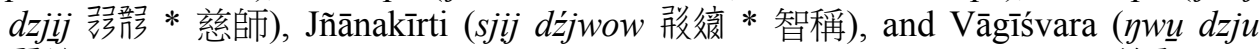
酸络* 語主), down to a Tibetan teacher named *brTson 'grus ( $k h u$ dju 钢茫 * 精 進). ${ }^{15}$ The Tangut śramana Dehui (tśhja źjir 微普 * 德慧) compiled *brTson-'grus's teachings into the text Keypoints after his encounter with the master probably during the mid-12th century. ${ }^{16}$ Without a direct mention of its authorship, the Notes was probably produced by Dehui's circle (if not directly by Dehui himself), as the work contains Dehui's own accounts of his learning experiences with *brTson 'grus. ${ }^{17}$ Those having Chinese translated titles in the DYM - no matter whether the corresponding Tangut edition is extant or not-emerged somewhat later, and were transmitted by State Preceptor Xuanzhao 玄照 at the turn of the 13th century. The lineage goes through Saraha, Śavaripa, and Maitrīpa in its Indian component, then proceeds to the Tibetan bKa' brgyud patriarchs Mar pa (1012-1097) and Mi la ras pa (1028/40$1111 / 23$ ), and finally reaches Xuanzhao. ${ }^{8}$

Alongside the classical Saraha-Maitrīpa line, the presence of Vimalakīrti, Jñānakīti, and Vāgiśvara in the Keypoint-Notes lineage is not typical of a Mahāmudrā transmission. The curious placement of the mythological figure Vimalakirti as the first patriarch adds to the sūtric tone of the lineage presentation. ${ }^{19}$ Jñānakīrti who succeeds Maitrīpa, despite the two Mahāmudrā-related works he left in the Tibetan bsTan-'gyur (canonical collection of translated treatises) ${ }^{20}$ is barely seen in Indo-Tibetan Mahāmudrā lineage accounts. The last Indian personality Vāgīśvara — attributed by the Keypoints as a Nepalese expert in the sixty-two deities Cakrasamvara mandala praxiscan almost certainly be identified with the 11th-century Nepalese Thang chung pa who

${ }^{15}$ See the Keypoints $(1 \mathrm{~b} 1-4 \mathrm{~b} 1)$. For a survey of these figures, see Solonin 2011: 285-288; 2012: $248-262$.

${ }^{16}$ According to the Notes (I: 4a5-6), the Keypoints was composed in a renshen 王申 year, either 1152 or 1212. Based on the years of Dehui's career, which ranged through the reign of Renzong 仁宗 (1139-1193), Solonin (2015: 428) dates the work to 1152. For Dehui's identity and career, see Dunnell 2009: 47-49; Solonin 2015: 439-440, Note 29.

${ }^{17}$ The Notes (X: 26a1-27b4) adopts a first person perspective to describe Dehui's experience studying with *brTson 'grus in Tsong kha ( $t$ sow $k a$ 邹瓶), the northeastern area of Tibet bordering the Tangut Xixia. For the translation of the relevant passage, see Solonin 2012: 245-246.

${ }^{18}$ See Solonin 2011: 283.

${ }^{19}$ Vimalakīrti did not gain as wide popularity in Tibetan Buddhism as in the Sinitic Buddhist milieu. In Xixia, however, the figure seems to have gained a certain degree of importance in the Tibetan environment. Solonin (2012: 251) notes another Tangut case of Vimalakirti's presence: the

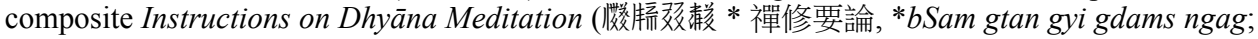
Tang.\#inv. 291\#4824), which consists of several short titles, is attributed to the collective composi-

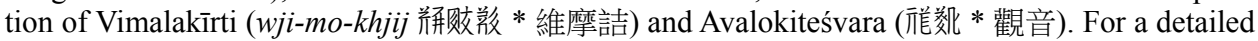
study of this Instructions on Dhyanna Meditation, see Yuan 2016 which further confirms that the work was transmitted by Pha dam pa Sangs rgyas.

${ }^{20}$ The two works Jñānakīrti left in the bsTan 'gyur are the *Tattvāvatāra (De kho na nyid la 'jug pa, P 4532) and the *Pāramitāyānabhāvanākramopadeśa (Pha rol tu phyin pa'i theg pa bsgom pa'i rim pa'i man ngag, P 5317=5456). 
later acquired the name 'Vāgīśvara' and played an instrumental role in the Cakrasamvara transmission from India to Tibet. ${ }^{21}$

As such, unlike Xuanzhao's lineage, whose Indo-Tibetan section is attested in Tibetan historiographical accounts, the Keypoints-Notes lineage is more of an ahistorical linking of diverse selected lineal segments into a structured totality through a distinctively Xixia mode of recognition and imagination. Moreover, it is interesting to note that the succession from Śakyamuni through the eight patriarchs traces a descending arc of spiritual accomplishments, possibly intent on a Buddhist eschatology. ${ }^{22}$

\section{The Notes Doxography: A Fourfold Presentation of Stages}

Before consecutively presenting the biographies of eight patriarchs, the Keypoints opens with a versified account of Śākyamuni's teaching career wherein he is shown

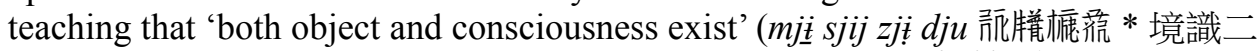

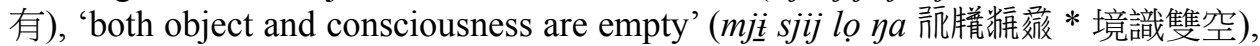

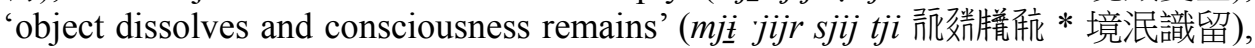

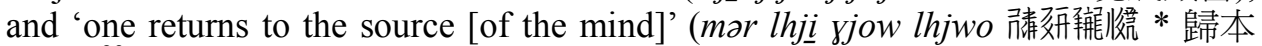
還源): $:^{23}$

The root teacher Sákyamuni (1) illuminated the world of the five-evil eon, dispelling the darkness of six gatis; (2) purified those possessed of three poisons, filling [the world] with the perfume water of eight qualities; (3) taught the Dharma according to his disciples' capacities, in full accord with the way of the three capacities; and (4) demonstrated reality through the mind, sealing his single mind with non-conceptuality.

As such, he explained that both object and consciousness exist, then uttered that both are empty, elucidated that object dissolves and consciousness remains, and concluded by pointing to the moment when one returns to the source [of the mind].

In his great samādhi, he passed on this quintessential teaching (upadeśa) to the Great Being Vimalakīrti.

${ }^{21}$ For a detailed survey of Vāgîśvara's religious activities as well as the relevant Tibetan historical records, see Wei 2013: 69-84.

${ }^{22}$ The spiritual hierarchy goes from the tenth $b h \bar{u} m i$ of the first patriarch, consecutively through the eighth, sixth, fourth, second and first bhumis of the second, third, fourth, fifth, and sixth patriarchs respectively, up to the prayoga and sambhära stages of the seventh and eighth patriarchs. See the Keypoints (inv. 2526: 1b1-4b8).

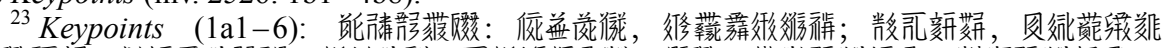

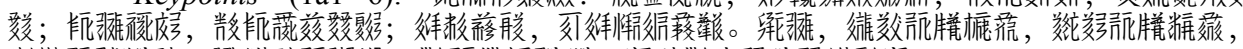

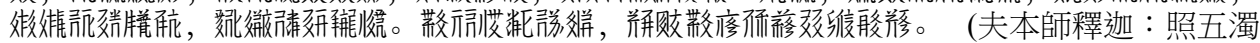
世, 除遣六趣黑暗; 洗三毒器, 盈滿八功香水 ; 依根說法, 隨順於三根道 ; 以心指真, 以無 念印一心。如是, 先解境識二有, 次說境識雙空, 後顯境泯識留乃至歸本還源。人於大禪定 時傳真要於維摩大者。) 
The Notes commentary on this paragraph takes the form of a doxography based on the doctrinal hierarchy of the four teachings, with the order of the second and third teachings reversed. ${ }^{24}$

The first three teachings in the Notes explication correspond respectively to

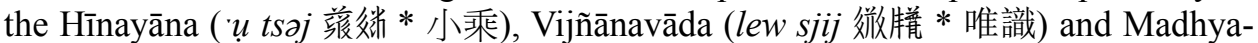
maka ( $g u$ tśja 政舞 * 中道) systems, each building upon and transcending the prior system all the way to the non-conceptual realisation characterised by the fourth level where 'one returns to the source [of the mind]'. Table 1 briefly presents the doctrinal architecture of the four progressively advancing stages of teaching structured by a syncretic Mahāyāna hermeneutics which combines classical Madhyamaka and Yogācāra models - that is, the three natures (so tsjịr 諼搌 * 三性; Skt. trisvabhāva), the two

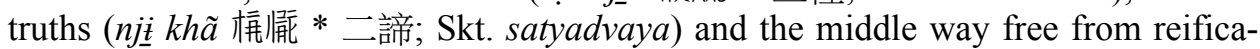

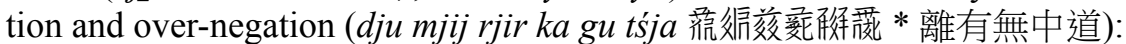

\section{Table 1. Four progressive teachings as charted out by the Notes doxography}

\section{Both object and consciousness exist}

\begin{tabular}{|c|c|c|}
\hline Parikalpita & Saṃvṛti-satya & 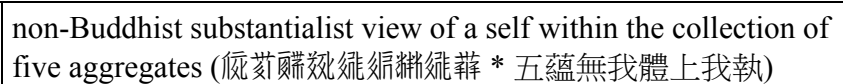 \\
\hline Paratantra & \multirow{2}{*}{$\begin{array}{l}\text { Paramārtha- } \\
\text { satya }\end{array}$} & 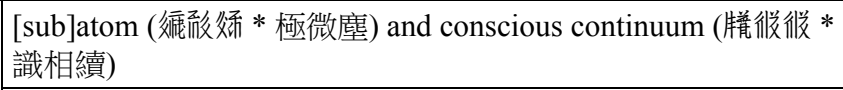 \\
\hline Parinișpanna & & selflessness in the person (较徘㛂 * 人無我) \\
\hline \multirow[b]{2}{*}{ Middle way } & $\begin{array}{l}\text { Transcend } \\
\text { reification }\end{array}$ & 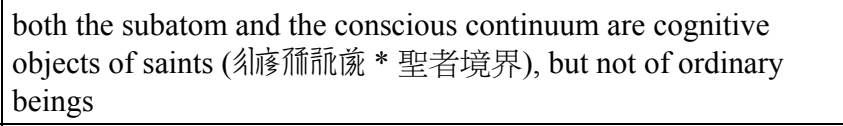 \\
\hline & $\begin{array}{l}\text { Transcend } \\
\text { over-negation }\end{array}$ & 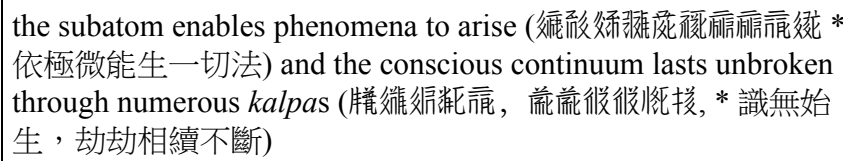 \\
\hline
\end{tabular}

${ }^{24}$ Notes I: $9 \mathrm{a} 1-12 \mathrm{~b} 5$. As explained in the Notes (I: 9b4-10a7), the Buddha taught 'object and consciousness are empty' in order to counter the substantialist adherence to both object and consciousness, an ill-conceived position potentially argued by his disciples leaning on his first teaching that 'both object and consciousness exist'. As 'object and consciousness are empty' would again lead to an attachment to emptiness, the notion that 'consciousness is real' is used in the formulation 'object dissolves and consciousness remains' to counter that fallacy. This is the order in which the Buddha taught. However, according to the Indian tradition of canonical arrangement, both 'object and consciousness exist' and 'object dissolves and consciousness remains' are provisional teachings, whereas 'object and consciousness are empty' is the root which counts as Madhyamaka established through pramānas. As such, 'object and consciousness are empty' is explicated right after 'object dissolves and consciousness remains'. 


\section{Object dissolves and consciousness remains}

\begin{tabular}{|c|c|c|}
\hline Parikalpita & Samvrṛti-satya & non-Buddhist and Hīnayānist substantialist views \\
\hline Paratantra & \multirow{2}{*}{ Paramārtha-satya } & 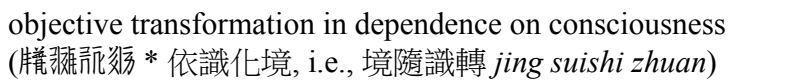 \\
\hline Parinișpanna & & 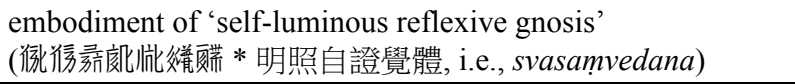 \\
\hline \multirow{2}{*}{ Middle way } & $\begin{array}{l}\text { Transcend reifi- } \\
\text { cation }\end{array}$ & 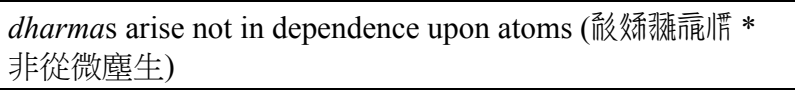 \\
\hline & $\begin{array}{l}\text { Transcend over- } \\
\text { negation }\end{array}$ & 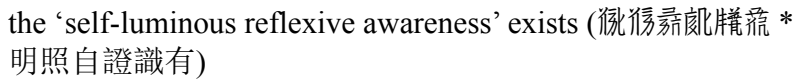 \\
\hline
\end{tabular}

\section{Both object and consciousness are empty}

\begin{tabular}{|c|c|c|}
\hline Parikalpita & Saṃvrti-satya & $\begin{array}{l}\text { [non-Buddhist,] Hīnayānist and Vijñāpti-mātrin substantialist } \\
\text { views }\end{array}$ \\
\hline Paratantra & \multirow{2}{*}{$\begin{array}{l}\text { Paramārtha- } \\
\text { satya }\end{array}$} & 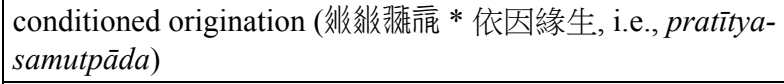 \\
\hline Parinișpanna & & 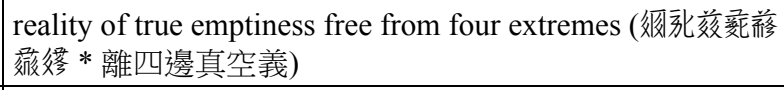 \\
\hline \multirow[b]{2}{*}{ Middle way } & $\begin{array}{l}\text { Transcend } \\
\text { reification }\end{array}$ & 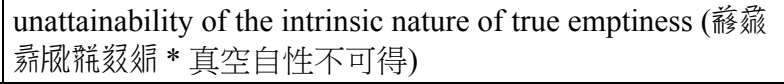 \\
\hline & $\begin{array}{l}\text { Transcend } \\
\text { over-negation }\end{array}$ & 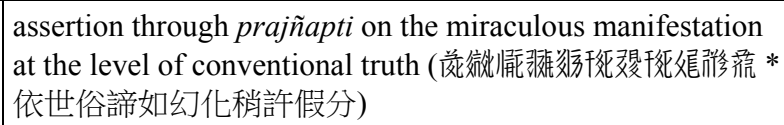 \\
\hline
\end{tabular}

\section{One returns to the source [of the mind]}

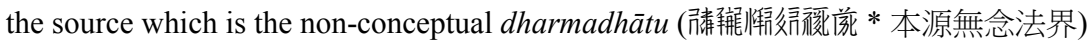

The doctrinal complex presented above maps out a path whereby one (1) first establishes the existence of object and consciousness upon subatoms and realises selflessness in the person, (2) then eliminates conceptuality toward object and abides in the status of consciousness-only, (3) then dissolves the attachment to consciousness and abides in Madhyamaka, and (4) finally returns to the source of the mind, or dharmadhātu. These hermeneutical devices provide scaffolding for the entire doctrinal architecture through progressive levels of negation and affirmation, that is, to establish each level's ultimate truth upon the negation of the one posited on the previous level. 


\section{Mahāyāna Philosophical Formulae: to Map out a Cognitive Modality}

The Notes' presentation of the first three levels of teachings - those of Hīnayāna, Vajñānavāda, and Madhyamaka, respectively - is echoed in the 8th- or 9th-century Tibetan doxographical tradition informed by Sāntarakṣita's (725-788) Yogācāra-Madhyamaka current. The fourth level shows new doctrinal developments within the Mahāyāna scholastic milieu, namely the rise of the Buddha-nature doctrine now occupying the position of ultimacy in the traditional Madhyamaka and Yogācāra frameworks.

The Buddhist doxographical practice of exegetical identification and classification of intellectual currents along a hierarchy took place within syncretistic traditions such as Bhavya's (c. 500-570) and Śāntarakșita's lines of Madhyamaka, ${ }^{25}$ and was continued by a long line of Tibetan scholars starting from Ye shes sde and dPal brtsegs (both $f l$. late 8 th or early 9th century). More than a polemical presentation of philosophical schools, Buddhist doxography instead presents progressive practical stages leading up to an ultimate end. As indicated by its emic expression siddhāntaor grub mtha' in Tibetan - the doctrinal hierarchy sketches different layers of accomplishment (siddha, grub pa), the end or limit (anta, mtha') of each to be surpassed by its succeeding stage. ${ }^{26}$

The fundamental point of dissent between Madhyamaka and Yogācāra was how the view of the phenomenal world as illusory can be accounted for in multiple layers. An early syncretic attempt can be found in Bhavya's works. To balance an overly transcendent Madhyamaka metaphysics with concerns about immanence, Bhavya assimilated all Buddhist scholastic schools (including Yogācāra) into Madhyamaka. ${ }^{27}$ Accepting the relative reality of external objects while still rejecting the Vijñānavādin reflexive awareness (svasamvedana), he understood cittamātra (mindonly) in the nominalist sense of svacittamayamatra - that is, the external world originated from the mind (citta) which is in itself insubstantial (adravyasat). ${ }^{28}$

Continuing Bhavya’s inclusive Madhyamaka line, Sāntarakșita in his Madhyamakālamkāra admitted the mind-only (sems tsam) notion at the samvrti level. ${ }^{29}$ Like

${ }^{25}$ Bhavya's Madhyamakahṛdayakārikā and Śāntarakṣita's Tattvasamgraha can be understood as the Indian precedents of the Buddhist doxographical tradition; see Tam and Shiu 2012: 10-11. For a brief introduction of these two works, see Ruegg 1981: 62-63, 89-90.

${ }^{26}$ See Tam and Shiu 2012: 47-56. For more discussions on the grub mtha' genre of Tibetan literature, see Mimaki 1982: 1-12.

${ }^{27}$ Lindtner (1997: 199) notes: 'Bhavya is the first, for all we know, to attempt to reduce svabhāvatraya to satyadvaya on a grand scale. He picks up the old distinction of samvrti-satya into the correct and wrong types, mainly to enable himself to reduce parikalpita- and paratantra- to those two forms of samvrrti-satya.' This, however, has inflicted on Bhavya criticisms from the Vijñānavādin camp.

${ }^{28}$ See Lindtner 1997: 187-189.

${ }^{29}$ See the MA (verses 92-93); sems tsam la ni brten nas su $\mid$ phyi rol dngos med shes par bya $\mid$ tshul 'dir brten nas de la yang | shin tu bdag med shes par bya || tshul gnyis shing rta zhon 
Bhavya, Śāntarakṣita assigned the Yogācāra parikalpita- and paratantra-svabhāvas to wrong and correct conventional truths (mithyā-samvrtisatya and tathya-samvvrtisatya), respectively. Unlike Bhavya, he accepted the self-luminous svasamvedane (rang rig rang gsal) as a true conventional truth leading to the Madhyamaka goal of establishing non-origination (anutpāda) free from the four extremes (catuskoți). ${ }^{30}$

As shown in both Ye shes sde's lTa ba'i khyad par and dPal brtsegs's lTa ba'i rim pa bshad pa, Tibetans first perceived Śāntarakșita's and Bhavya's Madhyamaka traditions as superior to Hīnayāna and Vijñānavāda, labelling each as 'YogācāraMadhyamaka' (rnal 'byor spyod pa'i dbu ma) and 'Sautrāntika-Madhyamaka' (mdo sde spyod pa'i dbu ma), respectively. Whereas both Sautrāntika- and Yogācāra-Mādhyamikas share in common the paramārtha postulation of emptiness (śünyatā) and non-origination (anutpāda), they differ in their conventional-truth descriptions about cittamätra - that is, while the former frames its understanding within a pratityasamutpāda (conditioned origination) ontology, the latter subscribes to a mental idealism of svasamvedana in achieving the same end. ${ }^{31}$ However, it seems Ye shes sde has accorded Sautrāntika-Madhyamaka a superior status at the samvrti level. ${ }^{32}$

However, while the presence of Sautrāntika-Madhyamaka in Tibetan scholarly exegesis seems to be only doxographical, Yogācāra-Madhyamaka came to prominence in Tibet as a scholastic tradition thanks to the proselytising activities of Santarakșita and his disciple Kamalaśila (c. 740-795). ${ }^{33}$ Thus, we have reason to believe that it was in reality Sāntarakșita's doctrinal system that informed the early Tibetan doxographical practice, and the presence of Bhavya's stemmed largely from the intellectual continuity between these two Madhyamaka currents which, however, were only doxographically distinguished in retrospect.

Let us now return to our Notes doxography. The first three levels of teaching envision a progressive model philosophically informed by Ye shes sde's doxography whereby one ascends the spiritual ladder consecutively through svasamvedana idealism and pratityasamutpāda ontology. ${ }^{34}$ The Notes doxography progresses from the

nas su | rigs pa'i srab skyogs 'ju byed pa $\mid$ de dag de phyir ji bzhin don | theg pa chen po pa nyid thob $\|$; for an English translation, see Ichigō 1989: 221, 223.

${ }^{30}$ Śāntarakṣita's teacher Jñānagarbha (c. 700-760), while inheriting Bhavya's system without much innovation, departed from the latter in embracing Dharmakīrti's style. It is in Sāntarakșita that the assimilation of Yogācāra into Madhyamaka reaches its culmination whereby Dharmakīrti's self-luminous svasamvedana is accepted as the true samvrrti-satya; see Lindtner 1997: 199-200; Ruegg 1981: 90-92.

${ }^{31}$ See the lTa khyad (180-186) and the ITa rim (260).

${ }^{32}$ See the lTa khyad (188).

${ }^{33}$ The major works belonging to Śāntarakșita's Yogācāra-Madhyamaka circle were translated into Tibetan around the turn of the 9th century. As for Bhavya's work, only the Prajñapradīpa was translated during the same period. See Ruegg 2000: 12-13.

${ }^{34}$ The existence of a Tangut hagiography of the 8th-century Great Perfection (rDzogs-chen) teacher Vairocana alludes to the possible presence of Ye shes sde in the Tangut collection. The Tangut text is titled 'A General Presentation of the Five-cycle Dharmadhātu' (tsjịr kiej ywa djij •jij gu bu

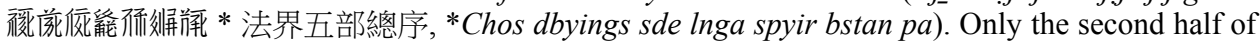
the work has survived. The extant part is concerning Vairocana's study journey to India. I thank Professor Kirill Solonin for exposing me to the existence of this text. Solonin's transcription of the 
Hīnayānist selflessness in the person, through the Vijñānavādin self-luminous svasaṃvedana, up to the Mādhyamika emptiness which is free from four extremes. This is a Yogācāra-Madhyamaka depiction. Moreover, in addition to establishing the selfluminous svasamvedana as conventional truth, the third level leaves room for Sautrāntika-Madhyamaka in positing a conventional truth of 'miraculous manifestation', under the rubric of 'transcending the over-negation', which corresponds exactly with the pratītyasamutpāda ontology.

Then what about the fourth level, 'returning to the source [of the mind]'? Tackling this question entails looking at the last centuries of the first millennium when the Mahāyāna doctrinal synthesis extended to-or subsumed - Buddhist tantric circles. Adding on to the traditional syncretic picture of Madhyamaka and Yogācāra, the Buddha-nature (Tathāgatagarbha) current was granted import as a discursive thread which gave expressions to the newly flourishing tantric gnoseology. ${ }^{35}$

Ratnākaraśānti (fl. c. 1000) — a great systematiser of tantric philosophy from the perspective of Mahāyāna scholasticism - put forth a fourfold yoga-bhümi path (rnal 'byor gyi sa bzhi po) for the progressive refinement of one's cognitive object (ālambana, dmigs pa): one first apprehends on external object (dngos po), then on mind-only (cittamātra, sems tsam), on suchness (tathatā, de bzhin nyid), and finally perceives the mahäyanna (theg pa chen po). ${ }^{36}$ The fourth stage, transcending the imagefree (nirābhāsa, snang ba med pa) status of the third, directly perceives the mahāyāna without any ālambanas. Ratnākaraśānti seems to have unpacked Śāntarakșita's paramārtha - which is postulated as existing beyond the Vijñānavādin svasamveda$n a$-into two stages, namely älambana on tathatā and perception of the mahāyāna. Accordingly, it is legitimate to speculate that the Notes doxography overlaps with Ratnākaraśānti's philosophical arrangement in that the third level of Madhyamaka corresponds to the alambana on tathata and the fourth level to the perception of the mahāyāna.

Moreover, combining both apophatic and cataphatic approaches in describing the experiential domain of ultimate reality (a direct perception of the mahāyanna built upon nirābhāsa), Ratnākaraśānti allowed room for the positive aspect of Buddhahood - characteristic of the Buddha-nature current - to unfold. A possible parallel of this in the Notes doxography is found in the expression 'source' (腈* 本 or 践*源) contained in the name of the fourth level.

text could be accessed through the link https://www.academia.edu/38166091/GreatImage.pdf. Vairocana - one of the first seven Tibetans to be ordained as Buddhist monks (sad mi mi bdun) —is said to have brought the mind-class (sems sde) and expanse-class (klong sde) teachings of Great Perfection from India to Tibet. According to the 'Dra 'bag chen mo, which includes a historiography of the Great Perfection transmissions from India to Tibet and an extensive hagiography of Vairocana, Vairocana is also known as Ye shes sde sūtra-wise; see the Bai 'dra (f. 96.4): mtshan kyang mdo ltar ye shes sde |. Karmay (2007: 30), however, considers this identification as 'simply a fancy', since Ye shes sde belongs to the family of sNa nam, while Vairocana seems to bear the family name Ba gor.

${ }^{35}$ Kamalaśîla seems to be one of the earliest Madhyamaka teachers to incorporate the Buddha-nature doctrine into scholastic discourse and thought; see Ruegg 1981: 94-95.

${ }^{36}$ See Ruegg 1981: 122-123. 
An example institutionally and temporally more immediate to our Notes doxography is found in the Assembly Teaching (tshogs chos) collections of sGam po pa bSod nams rin chen (1079-1153) who drew exoteric doctrinal inspiration mainly from Atiśa (982-1054), ${ }^{37}$ a disciple of Ratnākaraśānti. In the Tshogs chos legs mdzes $m a$, sGam po pa sketched a fourfold scheme for the fundamental reality (gnas lugs gtan la phab) by progressively eliminating conceptualisation (rnam par rtog pa thams cad gcod par byed pa). ${ }^{38}$ The ontological status of being (yin lugs) one has to undergo across the four stages includes that of appearance (snang $b a$ ) to be recognised as mind (sems), of mind to be recognised as the nature of reality (chos nyid), of the nature of reality to be recognised as the inexpressible (brjod du med pa), and of the inexpressible to be recognised as the Dharmakāya (chos kyi sku). It is therefore obvious that sGam po pa's scheme agrees perfectly with both Ratnākaraśānti's and that of the Notes doxography in terms of both meditative content and progressive structure.

\section{Concluding Remarks}

Table 2 is a graphic representation of the levels of teaching and practice in the systems or schemes discussed above. ${ }^{39}$

Table 2. Schemes found in different works

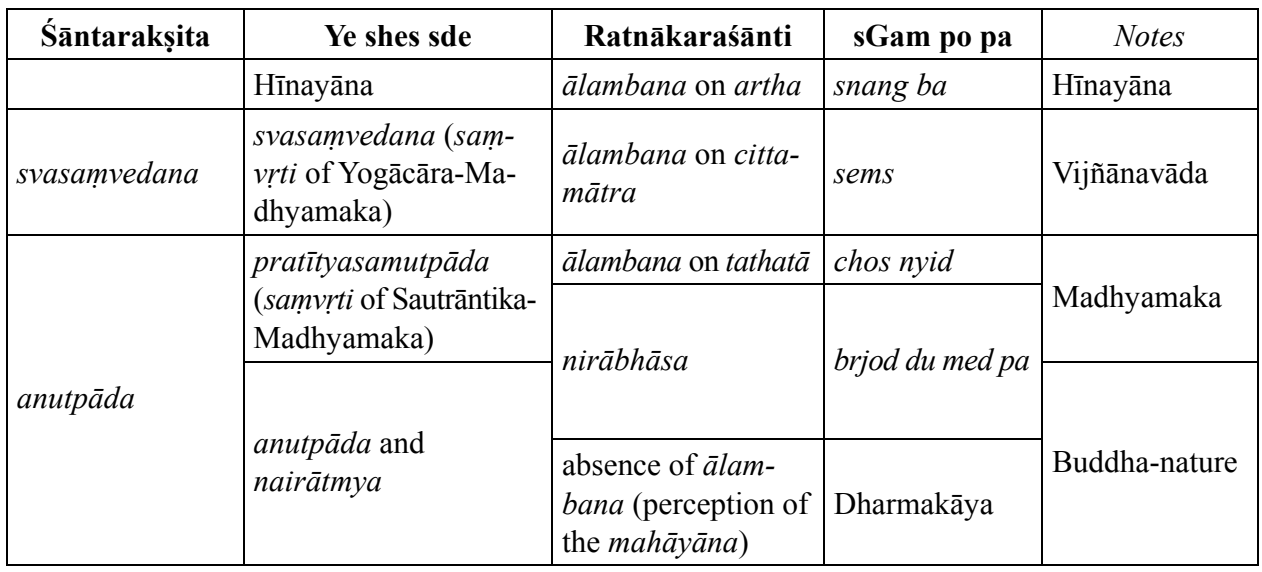

${ }^{37}$ Atiśa left a remarkable presence in the Xixia collection, either as the author of doctrinal compositions or an important personality in the tantric lineage accounts; see Solonin 2016.

${ }^{38}$ See the Tshogs legs (ff. 57a3-60a1).

${ }^{39}$ The graphic correspondence is only rough and for heuristic purposes. The typological parallels among systems do not necessarily imply historical inheritance. 
As much as philosophical insight lays a claim to universality across time and place, its discursive form is historically and culturally conditioned. In the Buddhist case, philosophical thinking and scholastic writing, including its soteriology and gnoseology, are structurally entwined with a consideration of spiritual praxis. ${ }^{40}$ The Notes doxography mirrors not so much a chronological and comparative presentation of different doctrinal schools as a scheme assigning teachings to rungs on a ladder leading to non-conceptual realisation. It sketches a fourfold scheme whereby a progressively deeper degree of reality unfolds in the practitioner's experiential domain. In its specifically Tangut expression, an orderly exposition of Hīnayāna, Vijñānavāda and Madhyamaka, shows a continuation with Ye shes sde's and dPal dbyangs's Tibetan doxographies informed by Śāntarakșita's Yogācāra-Madhyamaka tradition. Meanwhile, placing 'returning to the source [of the mind]' atop the ladder represents a tantric emphasis of the Buddha-nature doctrine which transcends the image-free cognitive status, a practice also adopted by Ratnākaraśānti and sGam po pa. However, it is perhaps more of the Notes' innovation that the Mahāyāna hermeneutical devices of three natures, two truths, and the middle way free from reification and over-negation are combined to scaffold the entire doctrinal architecture.

I conclude the article with some complementary information regarding the doxographical schemes at work in the discursive pool of the Tibetan-inspired collection of Tangut Buddhist texts. A dilapidated text titled Notes on the Keypoints Expli-

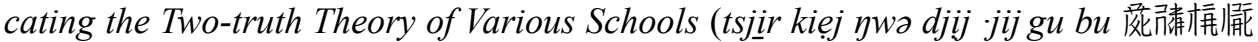

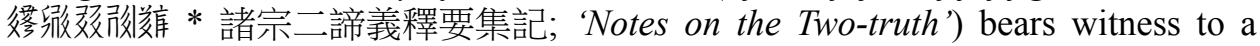
doxography different from that of the Notes. According to the Notes on the Two-truth, the causal vehicle (i.e., the sūtric or pāramiā mode) of Mahāyāna is divided into Yogācāra and Madhyamaka. While Yogācāra is further subdivided into the Sākāra and the Nirākāra types, Madhyamaka is subdivided into the Mayopama and the Apratișthāna types. ${ }^{41}$ This Mayopama-Apratișthāna division of Madhyamaka, which was not as well received as its Sautrāntika-Yogācāra equivalent during the snga dar (earlier transmission) phase of Tibetan Buddhism (7th-9th century), was confined to a small circle of tantric practitioners in India and therefore never had the chance to systematise properly. Thus, Tibetans inherited this scheme only in a very rudimentary form. ${ }^{42}$

\section{References}

\section{Sigla}

DYM Dasheng yaodao miji 大乘道要密集. 2 vols. Taipei: Ziyou chubanshe, 1962.

GS Khams gsum chos kyi rgyal po dpal mnyam med sgam po pa 'gro mgon bsod nams rin chen mchog gi gsung 'bum yid bzhin nor bu. 4 vols. Kathmandu and Delhi: Khenpo S. Tenzin and Lama T. Namgyal, 2000.

\footnotetext{
${ }^{40}$ See Ruegg 1995.

${ }^{41}$ As I am temporarily unable to access this Tangut text, I hereby thank Professor Kirill Solonin for kindly sharing his translation of the text with me.

${ }^{42}$ See Almogi 2010.
} 
P Peking bKa' 'gyur and bsTan 'gyur. Numbering based on: Daisetz T. Suzuki (ed.) (1955-1961): Eiin Pekin-ban Chibetto Daizōkyō 影印北京版チベット大藏經 [The Tibetan Tripitaka]. Kyoto and Tokyo: Tibetan Tripitaka Research Institute.

Tang. \# inv. The numbering system used in Gorbacheva and Kychanov 1963 for the Kharakhoto Tangut texts housed in the archive of the Institute of Oriental Studies in St. Petersburg. Each Khara-Khoto fragment under a numbered title (Tang.) was originally assigned an inventory number (inv.).

\section{Primary Sources}

\subsection{Tangut Works}

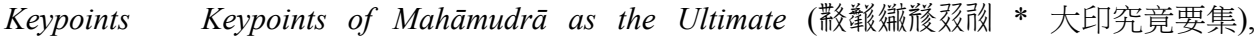
Tang.\#inv. 345\#2526 (xylograph, 27 folios).

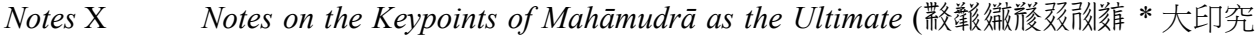
竟要集記), the final volume (commentary on the final part of the $D J Y$ which is missing in the currently available texts) and colophon, Tang.\#inv. 345\#2851 (manuscript, 26 folios).

\subsection{Tibetan Works}

Bai 'dra gYu sgra snying po, Bai ro'i rnam thar 'dra 'bag chen mo. Chengdu: Si khron mi rigs dpe skrun khang, 1995.

lTa khyad Ye shes sde, lTa ba'i khyad par. In: Bdud 'joms 2012, 172-253 (Tibetan text and Chinese translation).

lTa rim dPal brtsegs, lTa ba'i rim pa bshad pa. In: Bdud 'joms 2012, 254-279 (Tibetan text and Chinese translation)

Tshogs legs $\quad$ sGam po pa bSod nams rin chen, Tshogs chos legs mdzes ma. In GS: 443-451, Vol. 1.

\subsection{Indic Works}

MA Śāntarakṣita, Madhyamakālaṃkāra. In: Ichigō 1989: 185-224 (Tibetan text and English translation).

MAU Ratnākaraśānti, Madhyamakālaṃkāropadeśa. P 5586.

\subsection{Chinese Works}

GDX Guangming ding xuanyi 光明定玄義. In: DYM, Vol. 1.

\section{Secondary Sources}

Almogi, Orna 2009. Rong-zom-pa's Discourses on Buddhology: A Study of Various Conceptions of Buddhahood in Indian Sources with Special Reference to the Controversy Surrounding the Existence of Gnosis (jñanna: ye shes) as Presented by the Eleventh-century Tibetan Scholar 
Rong-zom Chos-kyi-bzang-po. Tokyo: The International Institute for Buddhist Studies of the International College for Postgraduate Buddhist Studies.

AlmoGi, Orna 2010. 'Māyopamādvayavāda versus Sarvadharmāpratișțhānavāda: A Late Indian Subclassification of Madhyamaka and its Reception in Tibet.' Journal of the International College for Postgraduate Buddhist Studies 14: 135-212.

BDud 'Joms, 'Jigs bral ye shes rdo rje 2012. The Doxographical System (grub mtha') according to the rNying ma Tradition (Ningmapai sibu zongyi shi). [Translated by Shek-wing TAM, Henry C. H. SHIU and William Alvin Hus.] Beijing: Zhongguo Zangxue Chubanshe.

BeCKwith, Christopher 1984. 'Hitherto Unnoticed Yüan-Period Collection Attributed to 'Phags Pa.' In: Louis Ligeti (ed.) Tibetan and Buddhist Studies Commemorating the 200th Anniversary of the Birth of Alexander Csoma de Körös. Budapest: Akadémiai Kiadó, 9-16.

CHEN Qingying 陳慶英 2003. 'Dasheng yaodao miji yu Xixia wangchao de zangchuan fojiao 大乘 要道密集與西夏王朝的藏傳佛教 [The Dasheng yaodao miji and Tibetan Buddhism in the Xixia Kingdom].' In: SHEN Weirong 沈衛榮 and XIE Jisheng 謝繼勝 (eds.) Xianzhe Xinyan 賢者新宴 III. Shijiazhuang: Hebei Jiaoyu Chubanshe, 49-64.

DALTON, Jacob 2005. 'A Crisis of Doxography: How Tibetans Organized Tantra during the 8th-12th Centuries.' Journal of the International Association of Buddhist Studies 28/1: 115-181.

DunNell, Ruth 2009. 'Translating History from Tangut Buddhist Texts.' Asia Major 22/1: 41-78.

DunNELL, Ruth 2011. 'Esoteric Buddhism under the Xixia (1038-1227).' In: Charles ORZECH (ed.) Esoteric Buddhism and the Tantras in East Asia. Leiden and Boston: Brill, 465-477.

Germano, David and William Waldron 2006. 'A Comparison of Ālaya-vijñāna in Yogācāra and Dzogchen.' In: Dinesh Kumar NaURIYAL (ed.) Buddhist Thought and Applied Psychological Research. London and New York: Routledge, 36-68.

Gorbacheva, Zoya I. and Evgenij I. Kychanov [ГорьАчевА, Зоя И., КычАНОв, Евгений И.] 1963. Список отождествлённых и определённых тангутских рукописей и ксилографов коллекиии Института Народов Азии АН СССР. Москва: Издательство восточной литературы.

HALBFASS, Wilhelm 1988. India and Europe: An Essay in Understanding. Albany: State University of New York Press.

ICHIGŌ Masamichi 一鄉正道 1989. 'Part III: Śāntarakṣita’s Madhyamakālaṃkāra.' In: Luis GóMEZ and Jonathan SILK (eds.) Studies in the Literature of the Great Vehicle: Three Mahāyāna Buddhist Texts. [Michigan Studies in Buddhist Literature.] Ann Arbor: Center for South and Southeast Asian Studies, University of Michigan, 141-240.

JACKSON, Roger 2005. 'Mahāmudrā.' In: Lindsay JonES, Mircea EliAdE and Charles ADAMS (eds.) Encyclopedia of Religion. [2nd ed.]. Detroit: Thomson Gale, 5596-5601.

JACKSON, Roger 2011. 'Mahāmudrā: Natural Mind in Indian and Tibetan Buddhism.' Religion Compass 5/7: 286-299.

KARMAY, Samten 2007. The Great Perfection (rDzogs chen): a Philosophical and Meditative Teaching of Tibetan Buddhism. Leiden: Brill.

KYсHANOv, Evgenij I. [КЫчАнОВ, Евгений И.] 1999. Каталог тангутских буддийских памятников Института Востоковедения Российской Академии Наук. Kyoto: University of Kyoto Press.

Li Fanwen 李范文 2012. Jianming xia-han zidian 簡明夏漢字典 [The concise Tangut-Chinese dictionary]. Beijing: Zhongguo Shehui Kexue Chubanshe.

LINDTNER, Christian 1997. “'Cittamātra” in Indian Mahāyāna until Kamalaśíla.' Wiener Zeitschrift für die Kunde Südasiens / Vienna Journal of South Asian Studies 41: 159-206.

LÜ Cheng 吕澄 1942. Hanzang fojiao guanxi shiliao ji 漢藏佛教關係史料集 [Documenta Buddhismi sino-tibetici]. Chengdu: Huaxi Xiehe Daxue Zhongguo Wenhua Yanjiusuo. 
MATHES, Klaus-Dieter 2006. 'Blending the Sūtras with the Tantras: The Influence of Maitrīpa and His Circle on the Formation of Sūtra Mahāmudrā in the Kagyu Schools.' In: Ronald DAVIDSON and Christian WeDEMEYeR (eds.) Buddhist Literature and Praxis: Studies in Its Formative Period 900-1400. Leiden: Brill, 201-227.

Mathes, Klaus-Dieter 2007. 'Can sūtra mahāmudrā Be Justified on the Basis of Maitrīpa's Apratișțhānavāda?’ In: Brigit KeLLER (ed.) Pramānakìtih: Papers Dedicated to Ernst Steinkellner on the Occasion of his 70th Birthday, Part 1. Wien: Arbeitskreis für tibetische und buddhistische Studien, Universität Wien, 545-566.

MATHES, Klaus-Dieter 2009. 'Maitrīpa's Amanasikārādhāra (“A Justification of Becoming Mentally Disengaged”).' Journal of the Nepal Research Center XIII: 3-30.

MiMAKI Katsumi 禦牧克己 (ed. and trans.) 1982. Blo gsal grub mtha'. Kyoto: University of Kyoto.

NevSKIJ, Nikolai [Невский, Николай] 1960. Тангутская филология. 2 vols. Москва: Издательство восточной литературы.

NiSHIDA, Tatsuo 西田龍雄 1977. 'Catalogue of Tangut Translations of Buddhist Texts.' In: NiSHIDA Tatsuo (ed.) Seikabun Kegonkyō 西夏文華嚴經 [The Hsi-Hsia Avatamsaka Sūtra] 3. Kyoto: University of Kyoto Press, 13-59.

NishidA, Tatsuo 1999. 'Preface.' In: KyCHANOv 1999: i-xlvii.

RuEgG, David Seyfort 1981. The Literature of the Madhyamaka School of Philosophy in India. [History of Indian Literature 7.] Wiesbaden: Harrassowitz.

RuEGG, David Seyfort 1995. 'Some Reflections on the Place of Philosophy in the Study of Buddhism.' Journal of the International Association of Buddhist Studies 18/2: 145-181.

RuegG, David Seyfort 2000. Three Studies in the History of Indian and Tibetan Madhyamaka Philosophy. [Studies in Indian and Tibetan Madhyamaka Thought 1.] Wien: Arbeitskreis für tibetische und buddhistische Studien, Universität Wien.

SHEN Weirong 沈衛榮 2007. “"Dasheng yaodao miji” yu Xixia Yuanchao suochuan xizang mifa 《大乘要道密集》與西夏、元朝所傳西藏密法 [The Dasheng yaodao miji and Tibetan esoteric Buddhism under the Xixia and Yuan].' Zhonghua Foxue Xuebao 中華佛學學報 20: 251-303.

SHEN Weirong 沈衛榮 (ed.) 2017. Zangchuan fojiao zai xiyu he zhongyuan de chuanbo: Dasheng yaodao miji yanjiu chubian 藏傳佛教在西域和中原的傳播：《大乘要道密集》研究初 編 [Tibetan Buddhism in Central Eurasia and China proper: First collection of studies on the Secret Collection of Works on the Essential of Mahāyāna]. Beijing: Beijing Shifan Daxue Chubanshe.

Solonin, Kirill 2011. 'Mahāmudrā Texts in the Tangut Buddhism and the Doctrine of "No-Thought".' Xiyu Lishi Yuyan Yanjiu Jikan 西域歷史語言研究集刊 2: 277-305.

Solonin, Kirill 2012. ‘Xixiawen “dashouyin” wenxian zakao 西夏文 “大手印” 文獻雜考 [Miscellanea of the Tangut Mahāmudrā literature].’ In: SHEN Weirong 沈衛榮 (ed.) Hanzang foxue yanjiu: wenben, renwu, tuxiang he lishi 漢藏佛學研究 : 文本、人物、圖像和歷史 [Sino-Tibetan Buddhist studies: texts, figures, images and history]. Beijing: Zhongguo Zangxue Chubanshe, 235-267.

Solonin, Kirill 2015. 'Dīpamkara in Tangut Context: An Inquiry into the Systematic Nature of Tibetan Buddhism in Xixia (Part 1).' AOH 64/4: 425-451.

Solonin, Kirill 2016. 'Dīpamkara in Tangut Context: An Inquiry into the Systematic Nature of Tibetan Buddhism in Xixia (Part 2).' AOH 69/1: 1-25.

Sun Bojun 孫伯君 2014. 'Further Reflections on the Relation between the Dasheng Yaodao Miji and Its Tangut Equivalents.' Central Asiatic Journal 57: 111-122.

SUN Bojun 孫伯君 and NIE Hongyin 聶鴻音 2018. Xixiawen zangchuan fojiao shiliao: 'dashouyin' fa jingdian yanjiu 西夏文藏傳佛教史料：‘大手印” 法經典研究 [Sources of Tibetan Bud- 
dhist history: studies in Tangut texts of the Mahāmudrā teachings]. [The Monograph Series in Sino-Tibetan Buddhist Studies.] Beijing: Zhongguo Zangxue Chubanshe.

TAM, Shek-wing and Henry C. H. SHIU 2012. 'Introduction.' In: BDUD 'JOMS 2012: 10-59.

WEI Wen 魏文 2013. 11-12 shiji shangle jiaofa zai Xizang he Xixia de chuanbo-yi liangpian Xixia hanyi mijiao wenshu he zangwen jiaofashi wei zhongxin 11-12世紀上樂教法在西藏和西 夏的傳播 - 以兩篇西夏漢譯密教文書和藏文教法史為中心 [A study of the transmission of Cakrasamvara teachings in Tibet and Xixia, 11-12th century: Based on two Chinese tantric Buddhist texts of Xixia and the Tibetan historical records]. (PhD dissertation, Renmin University of China, Beijing.)

YUAN Yaxuan 袁雅瑄 2016. Xixiawen Chanxiuyaolun kaoshi 西夏文《禪修要論》考釋 [An examination of the Tangut work Chanxiu yaolun]. (MA Thesis, Renmin University of China, Beijing.) 
